Historic, Archive Document

Do not assume content reflects current scientific knowledge, policies, or practices. 
62.39

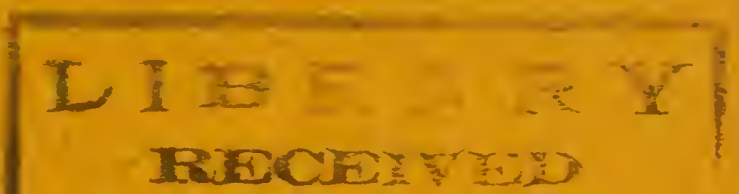

* SEP 191923 *

U. S. Dopertaneart of Agriceriture.
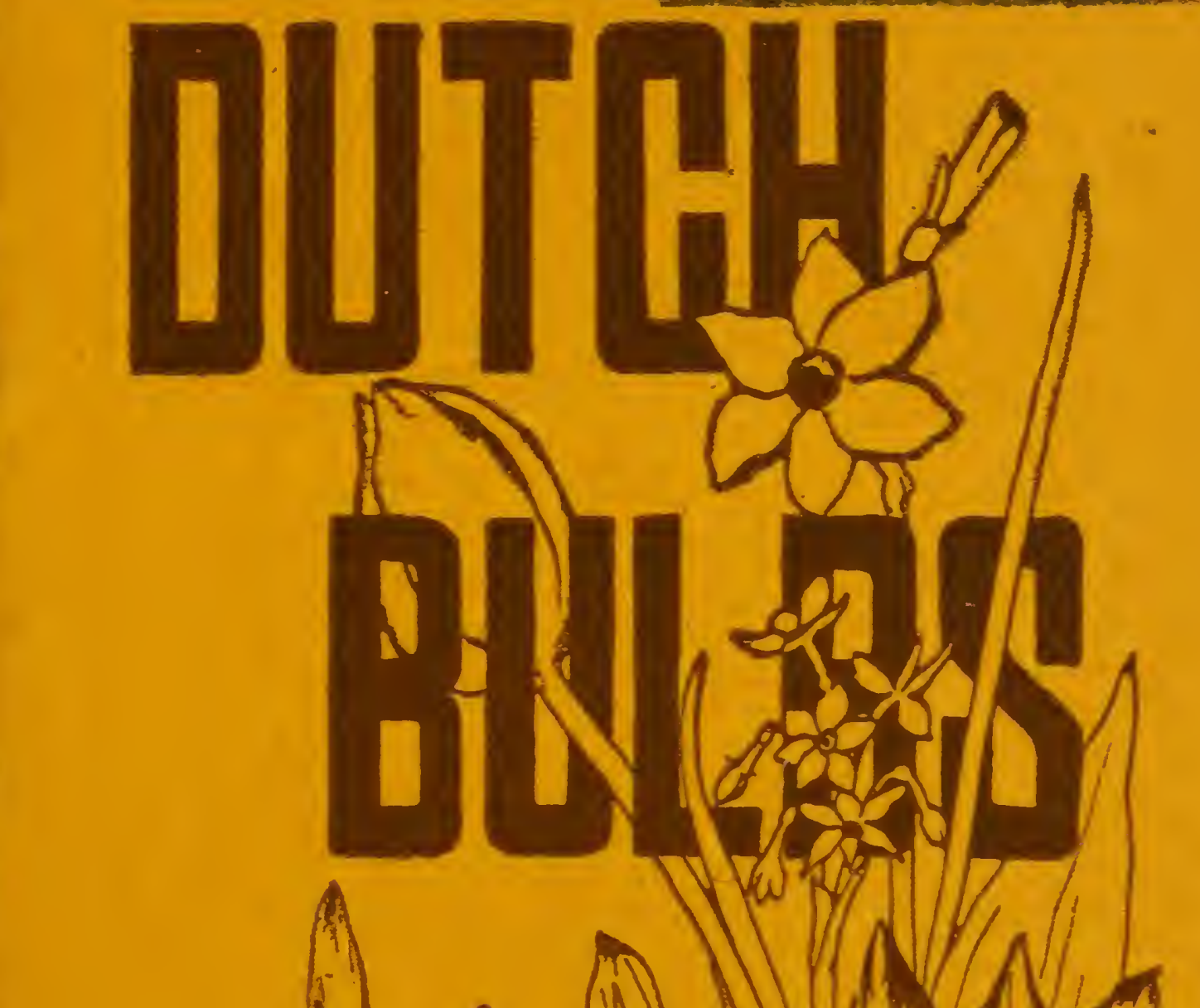

A

.
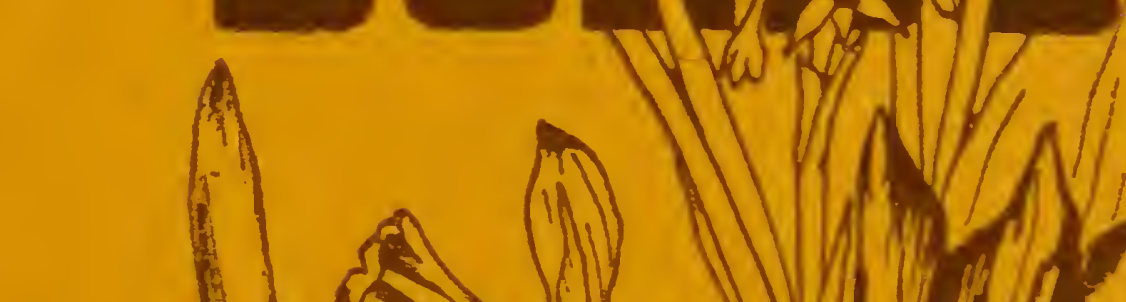


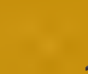

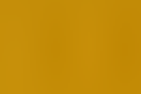

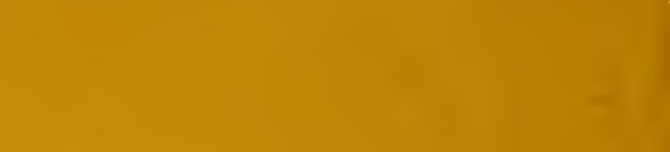

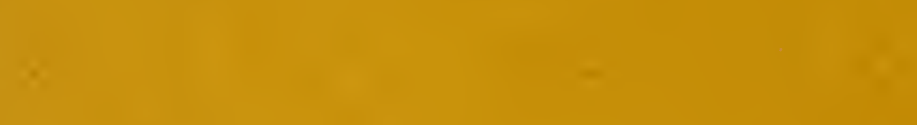

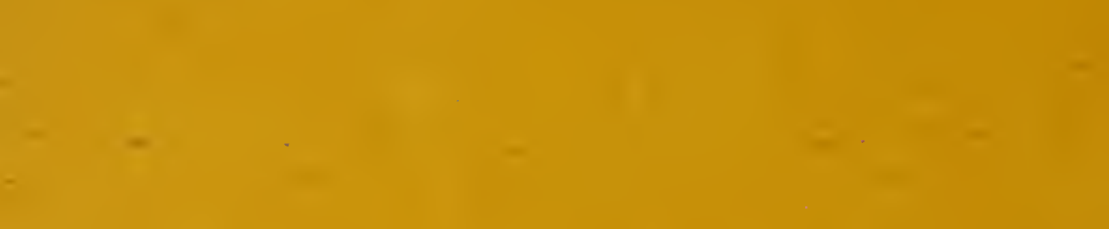

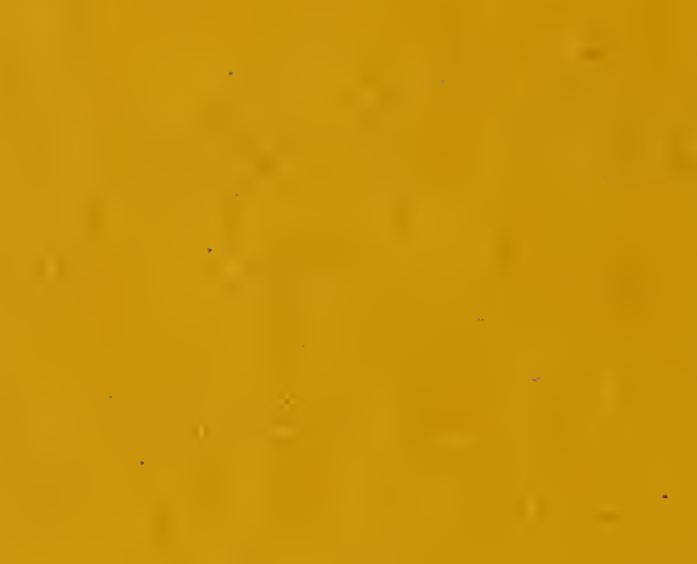

$=$

1)

-

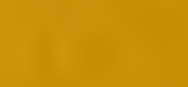

$$
x+10 x
$$

1

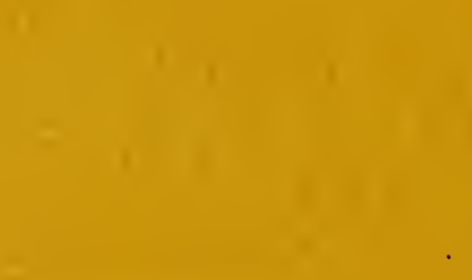

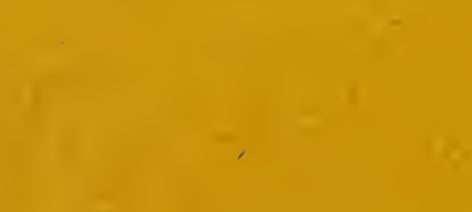

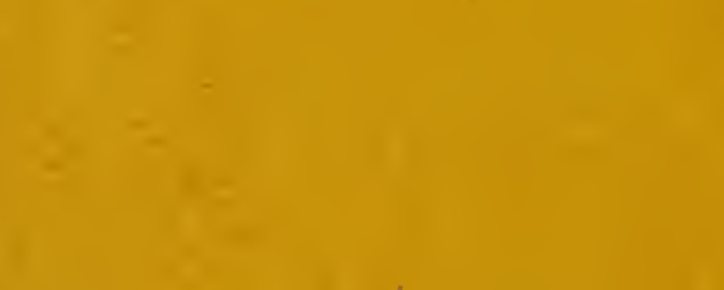

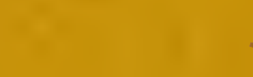

$n$

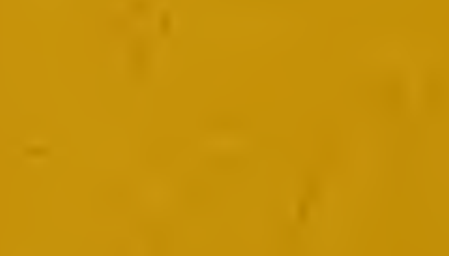

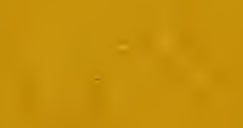

1

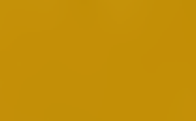

(a)

tas

$-$

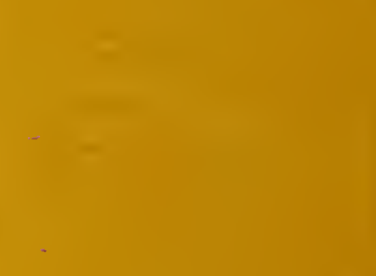

19.

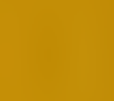

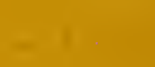


WHOLESALE ONLY

1911

WHOLESALE CATALOGUE

$\mathrm{OF}$

DUTCH GROWN BULBS

\section{GROWN BY \\ THE HORTICULTURAL CO.}

WHOLESALE BULB GROWERS

Bulb Farms

Limmen, Holland

Europe

Main Office

Worcester, Massachusetts

U. S. A.

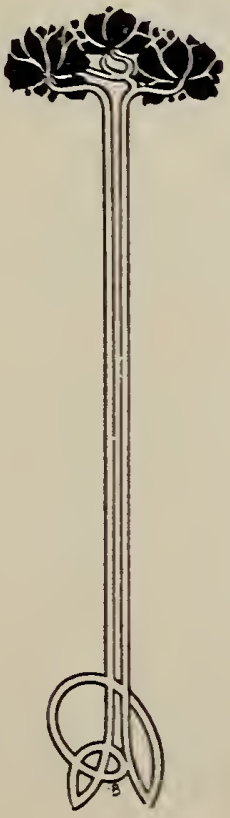

CABLE ADDRESS: "HORTO"

A B C CODE, 5th Edition, Used 


\section{THE \\ HORTICULTURAL COMPANY}

WORCESTER, MASSACHUSETTS, U. S. A.

To the Trade:

The Horticultural Company takes pleasure in offering this their first Whosesale Bulb Catalogue to the AMERIGAN TRADE.

Our BULB FARMS are located at LIMMEN, HOLLAND.

Our OFFICES are very centrally located at WORCESTER, MASS., where all correspondence, etc., should be directed.

Mr. J. Schermer, the resident Grower and Manager of the HORTICULTURAL CO.'S BULB FARMS at LIMMEN, HOLLAND, has established and holds a very enviable reputation and business relation with the EUROPEAN Bulb TRADE, and with a corps of men, most of whom have spent their lives on our bulb farms, under his supervision, together with the best methods of cultivation, the best soils and the best locations, in the HOLLAND BULB BELT, insures stock WELL GROWN-TRUE TO NAME-and of EXCEPTIONAL QUALITY.

As may be noted, we have listed mostly those varieties of BULBS which are in demand on this Continent, and grown by us in large quantities, but through favorable connections, we are in position to quote you on anything in THE DUTCH BULB LINE at REASONABLE PRICES.

We bespeak for our Messrs. Adrian van Leeuwen, Jr., and Hugo H. DeWildt, both American members of THE HORTICULTURAL CO., and who will visit you this season, your good will and a fair share of your patronage.

\section{QUALITY FIRST.}

Serving you with stock of the BEST QUALITY which the BEST SOILS and the BEST LOGATIONS can produce, we are confident of YOUR SUCCESS as DEALER or PLANTER and of OURS as SELLERS of HOLLAND'S BEST BULBS.

Respectfully,

\section{THE HORTICULTURAL COMPANY.}

A B C Code, 5th Edition. Cable: "Horto, Worcester."

\begin{tabular}{|c|c|c|c|c|c|c|c|}
\hline$a r a b$ & $=$ & 100 & irksome & $=$ & 5000 & quartz & 40,000 \\
\hline bison & $=$ & 250 & joy & $=$ & 6000 & razor & 50,000 \\
\hline cort & $=$ & 500 & knife & $=$ & 7000 & squash & 60,000 \\
\hline 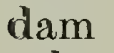 & $=$ & 1000 & lump & $=$ & 8000 & turk: & 70,000 \\
\hline$e c$ & $=$ & 2000 & moth & $=$ & 9000 & ulan & 80,000 \\
\hline & $=$ & 2500 & narcotic & $=$ & 10,000 & vast & $=90,000$ \\
\hline goa & $=$ & 3000 & ozone & $=$ & 20,000 & waste & $=100,000$ \\
\hline & $=$ & 4000 & perch & $=$ & 30,000 & & \\
\hline
\end{tabular}




\section{THE \\ HORTICULTURAL COMPANY, \\ WORCESTER, MASSACHUSETTS.}

\section{TERMS AND REMARKS.}

ORDER EARLY: "The early bird catches the worm," and as we in fairness to everybody fill orders in the same rotation in which we receive them, it is advantageous to you to be THE EARLY BIRD.

WHEN ORDERING.-Numbers placed before names of articles in our list may be used instead of names.

TIME OF SHIPMENT.-Our bulbs are usually ready for exportation in AUGUST or beginning SEPTEMBER.

SELEGTION AND PACKING are done under our PERSONAL SUPERVISION, and the latter charged at ACTUAL COST.

TRANSPORTATION INSURANCE, Etc.-Unless ordered to the contrary, we have all shipments insured against maritime losses at cost, but are not responsible for any damages to the stock after delivery to common carriers.

NON-WARRANTY.-It is plainly to our mutual interest that we guarantee and send out ONLY WELL-RIPENED STOGK, TRUE to NAME and COLOR, but we will not assume any responsibility for cultural behavior which is beyond our control.

It is hereby understood and mutually agreed between purchaser and this company that orders are accepted and filled under these conditions only.

PRICES are net at our BULB FARMS, LIMMEN, HOLLAND. 50 bulbs at 100 rate, 500 at 1000 , and 5000 at 10,000 rate.

ACCOUNTS are due three months from date of invoice at Worcester, Mass., and payable by our sight draft, unless other agreements of liquidation are agreed upon and written on original order.

DISGOUNTS.-Five per cent. discount is allowed on all accounts paid within 30 days from date of invoice.

UNPACKING.-All bulbs should be unpacked at once upon receipt and put in dry cool storage, to prevent them from getting mouldy.

TULIPS, however, may be left in their original packages until used. 


\section{HYACINTHS.}

\section{Miniature or Dutch Roman.}

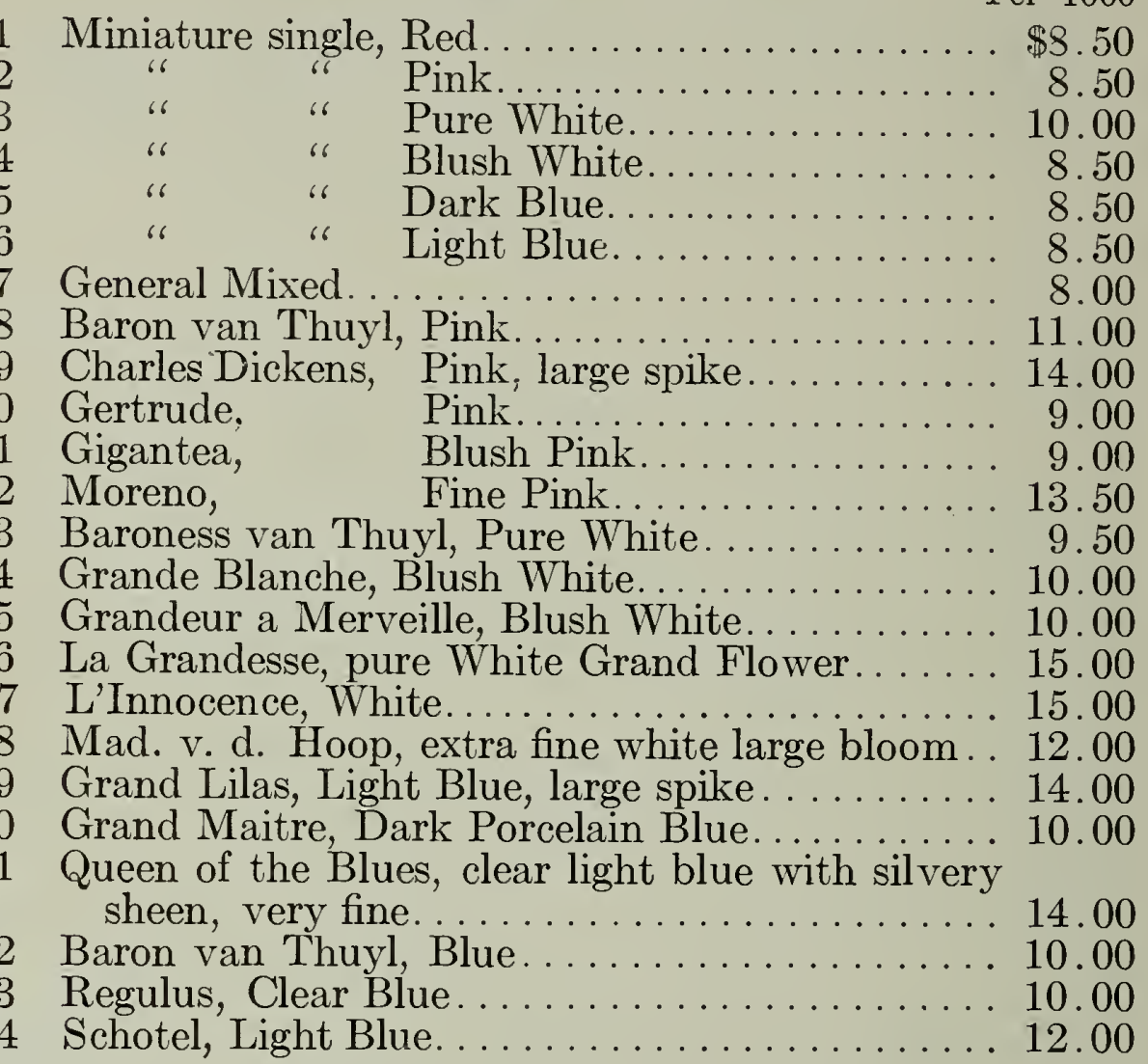

\section{HYACINTHS-Second Size.}

Single Red.

Robert Steiger, Carmine Red............. \$19.00

Baron van Thuyl, Pink................ 22.00

Cardinal Wiseman, Rosy Pink . . . . . . . . . . 22.00

Charles Dickens, Fine Pink............. 30.00

Gertrude, Rosy Pink. . . . . . . . . . . . . . . . . 18.00

Gigantea, Blush Pink ................. . 21.00

Belgian King, Fine Scarlet... . . . . . . . . . 20.00

Moreno, Very Fine Pink................... 23.00

Norma, Large Bell Pink. . . . . . . . . . . . 22.25

\section{HYACINTHS-Second Size.}

Single White.

Baroness van Thuyl, White.

$\$ 20.00$

Grande Blanche, Blush White.............. 19.50

Grandeur a Merveille, Blush White........... 20.00

Blanchard, Extra Early White. . . . . . . . . . . 22.00

38 La Grandesse, The White, very fine . . . . . . . 30.00

L'Innocence, Pure White .................. 28.00

Madame v. d. Hoop, Large Bells, White...... . 24.00

Paix de l'Europe, Pure White............ 22.00

Voltaire, Creamy White................ 24.00

La Franchise, Waxy White, late............ 22.00

Angenis Gristina, White.................. 25.00

45 Mr. Plimsol, Fine Blush White.......... 22.00

\section{HYACINTHS-Second Size.}

Single Blue.

Baron van Thuy!, Dark Blue, early.

Charles Dickens, Porcelain Blue.

Grand Lilas, Light Blue.

Grand Maitre, Porcelain Blue............. 21.00

King of the Blues, Dark Brilliant............. 22.00

51 La Peyrouse, Light Blue ...... . . . . . . . . . 19.00

52 Marie, Fine Dark Blue................. 18.50 
53 Queen of the Blues, Clear Light Blue . . . . . . . . .\$2\&.00

54 Regulus, Porcelain Blue................ 1900

55 Schotel, Fine Light Blue.............. 24.00

56 Pieneman, Large Porcelain Blue............ 20.50

57 Blondin, Large Bells, Porcelsin Blu־........ 21.00

\section{HYACINTHS-Second Size.}

Single Yellow.

Per 1000

58 King of the Yellows, Bright Golden Yellow, extra. $\$ 24.00$

59 La Pluie d'Or, Bright Yellow . . . . . . . . . . . . . . 24.00

60 Ida, early, Finest Early Yellow forcer......... 28.00

\section{HYACINTHS-Top Size.}

Single Red.

Per 100

1 Baron van Thuyl, Easily Forced Early Pink.... \$4.00

62 Cardinal Wiseman, Rosy Pink, fine spike...... 4.75

63 Caraignac, extra fine exhibition variety, Salmon Pink ......................... 5.00

64 Charles Dickens, The Finest of the Pinks, always satisfactory.

65 Gen. Pellissier, Bright Carmine Red, easy forcer

66 Gertrude, Extra Fine Pink, for all purposes. . . . . .

67 Grand Vainquer, Fine Early Tall Pink. . . . . . .

Belgian King, Scarlet, The Best

70 Uoreno, Extra Dine Pink for , white ey well as forcing..................... 4.75

71 Norma, Large Bell, Soft Pink ...............

72 Robert Steiger, Deep Crimson................

\section{HYACINTHS-Top Size.}

\section{Single White.}

Baroness van Thuyl, Very Early White.

British Queen, a Grand White, with extra large bulbs.

S2 L'Innocence, the most used variety for white, easy forcer. .

\$3 Mad. v. d. Hoop, White flower; grows well above the leaves ........................ 4.25

$\$ 4$ Paix de l'Europe, Large Drooping Flowers, pure White.

\section{HYACINTHS-Top Size.}

\section{Single Blue.}

Baron van Thuyl, Dark Blue, with compact spike $\$ 3.75$

88 Charles Dickens, Dark Porcelain Tariety, universally liked.

89 Czar Peter, Fine Porcelain Blue, easily forced....

90 Grand Lilas, One of the Finest All Around Blues, a very fine porcelain blue.

91 Grand Maitre, Deep Porcelain Blue, a grand spike.

94 Marie, Dark Blue. . . . . . . . f . . . bedding. . . . . . 
95 Grand Monarch, Porcelain Blue......... \$4.25

96 Enchantress, Clear Light Blue, an exceptional fine variety for exhibition.............. 6.00

97 Blondin, Fine Porcelain Blue, early . . . . . . . . . . . 4.00

98 Pieneman, Dark Porcelain Blue, large florets . . 3.75

99 Queen of the Blues, Light Blue, extra fine . . . . . . 5.50

100 Regulus, Light with Dark Stripe . . . . . . . . . . . . 3.25

101 Schotel, Very Early Porcelain Blue............ 5.00

\title{
HYACINTHS-Top Size.
}

\author{
Single Yellow.
}

102 Ball of Gold, Golden Yellow, large spike.

103 King of the Yellows, extra early, fine, clear yellow for outdoor work $\ldots \ldots \ldots \ldots \ldots \ldots \ldots \ldots$

104 Ida, Fine Yellow, excellent for forcing. . . . . . . . .

105 La Pluie d'Or, Bright Yellow . . . . . . . . . . . . . . .

106 Alida Jacoba, Dark Yellow . . . . . . . . . . . . . .

107 Sonora, Nankeen Yellow, large flower..........

\section{BEDDING HYACINTHS.}

The stocks used are bulbs of very good size and, though without names, are not made up of different varieties.

As they are cheap for the quality, they are used in enormous quantities, always giving satisfaction for forcing as well as out of doors.

\section{SINGLE BEDDING HYACINTHS.}

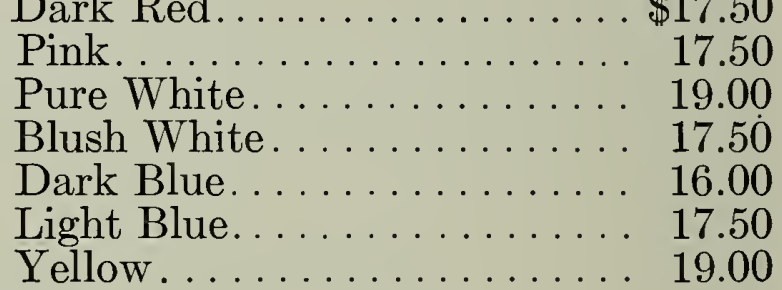

\section{DOUBLE BEDDING HYACINTHS.}

115

\section{DOUBLE NAMED HYACINTHS-Top Size.}

Double Red.

Per 1000

Double Bedding, All Colors Separate: except white and blush white.... $\$ 19.50$ " " " White...................... 22.00 MIXED HYACINTHS.

Single Mixed, Red, all shades. . . . . . . . . . . . \$12.50

\begin{tabular}{|c|c|c|c|}
\hline 66 & 6 & White, all shades... & 14.00 \\
\hline " & “ & Blue, all shades.... & 12.50 \\
\hline 6 & "6 & Red and Dark Red & 12.50 \\
\hline ، & “ & Pink and Rose... & 12.75 \\
\hline “ & ، & Pure White.... & 15.00 \\
\hline 66 & ، & Blush White. & 13.50 \\
\hline 66 & ، & Blue and Dark Blue & 13.00 \\
\hline ، & ، & Light Blue. . . . . . . . & 13.00 \\
\hline 6 & “ & Yellow ......... & 15.00 \\
\hline "6 & "، & All Colors Mixed. & 12.00 \\
\hline
\end{tabular}

Bouquet Royal, Salmon Pink 
Double White.

Per 100

136 Bouquet, Roval Pure White............. \$4.25

137 Flevo, Pure White.................. 4.50

138 Isabella, Blush White, fine for exhibition...... 4.00

139 La Grandesse, White.................. 6.00

140 La Tour d' Aurergne, Earliest, large spike, Thite 4.25

141 La Virginite, Blush White................. 4.00

Double Blue.

Per 100

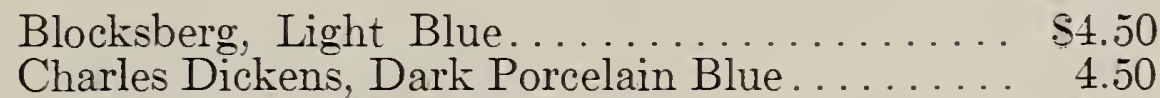

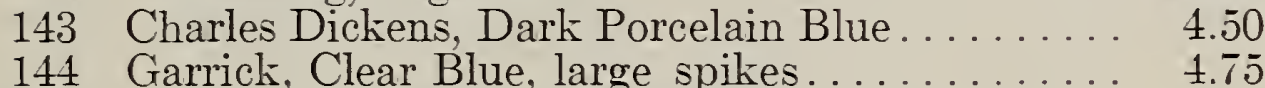

145 Gen. Kohler, Fine Porcelain Blue . . . . . . . . . 5.50

146 Tan Speyk, Lilac Blue, large............ 5.50

Double Yellow.

147 Sunflower, Large Pure Yellow............. \$4.25

148 Goethe, Bright Light Yellow . . . . . . . . . . . $\quad 4.00$

\section{DOUBLE NAMED HYACINTHS FOR BEDDING.}

Per 1000

149 Bouquet Tendre, Red . . . . . . . . . . . . . . . . . . \$33.50

150 Bouquet Royal, Salmon Pink... . . . . . . . . . 33.50

151 Lord Wellington, Large Pink. . . . . . . . . . 33.50

152 Blocksberg, Light Blue................ 33.50

153 Gen. Kohler, Porcelain Blue . . . . . . . . . . 33.50

154 Garrick, Dark Blue. ................... 33.50

155 La Tour d'Auvergne, Pure White . . . . . . . . 32.00

156 La Virginité, Blush White............. 32.00

Hyacinths per 100 , add 10 per cent. to 1000 rate.

\section{TULIPS.}

Our mixtures are made up of varieties which flower about the same time and are of the same height, and not to be compared with the ordinary mixtures generally sent out.

Single, early, fine mixed 3.25 per 100030.00 per 10000

\section{SINGLE EARLY TULIPS INIMIXTURE.}

159

160

161

162

163

Single Early Tulips, Mixed, White.......... \$5.00

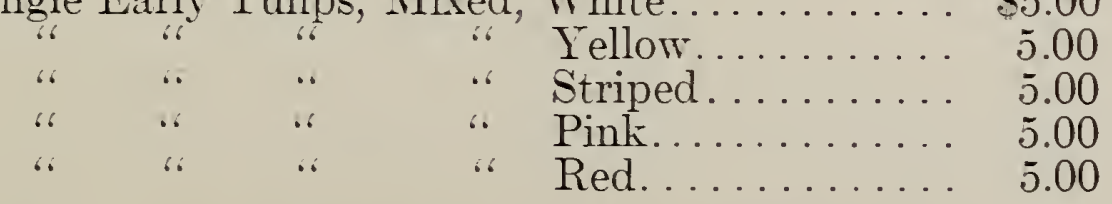

\section{SINGLE EARLY TULIPS NAMED.}

Belle Alliance, Scarlet. . . . . . . . . . . . . . 12.00

167 Canary Bird, Yellow............................. 6.75

168 Chrysolora, Golden Yellow . . . . . . . . . . . . 4.00

169 Cottage Maid, Pink...................... 4.50

170 Cramoisi Brilliant, Early Scarlet .............. $\quad 6.50$

171 Couleur Cardinal, Bright Vermilion .......... 10.00

172 Duchess de Parma, Orange Yellow, margined, good forcer.......................... 6.50

173 Duc de Berlin, Early Red and Yellow . . . . . . . . 12.00 
Duc van Thol, Red and Yellow .......... \$6.00

175

176

178

179

180

181

182

183

184

185

186

187

188

189

190

191

192

193

194

195

196

197

198

199

200

201

202

203

204

205

206

207

208

209

210

211

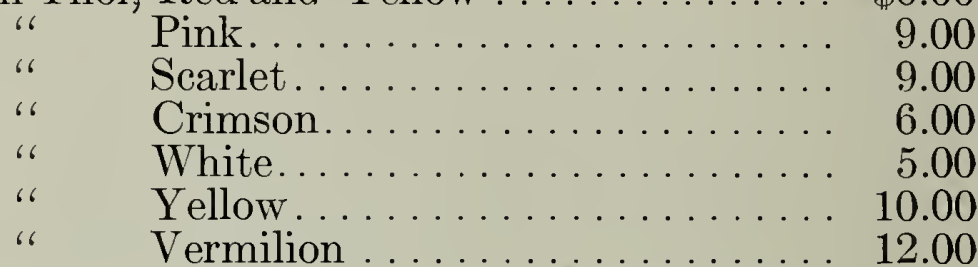

Goldfinch Sweet Scented Golden Yellow, extra fine for all purposes. . . . . . . . . . . . . .

Jacht van Delft, White. . . . . . . . . . . . 4.50

Joost van Vondel, Red .................... 6.50

White, The finest White, outdoors 14.00

Keiserskroon, Bright Red and Golden Yellow Band

L'Immaculee, Pure White, good forcer. . . . . . . . . .

King of the Yellows, Fine Golden Yellow . . . . . . . . .

La Reine, Pure White. No need to say anything about this variety.

Fancy selected, per $10,000 \$ 55.00 \ldots \ldots \ldots \ldots 6.50$

First grade, per $10,000 \$ 40.00 \ldots \ldots \ldots \ldots \ldots .4 .50$

Mon Trésor, Pure Yellow, fine forcer and bedder 7.50

Pottebakker, White, Pure White, good forcer . . . 8.00

" Scarlet................. 10.00

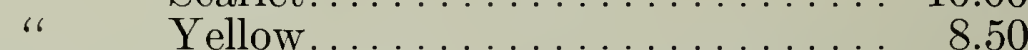

Prince of Austria, Bright Orange Vermilion, a

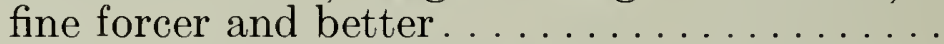

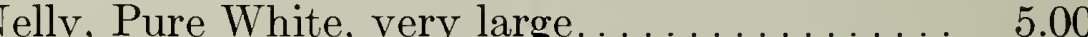

Princess Marianna, White, tinted Pink, very large 7.00

Proserpine, Deep Carmine, Satiny Pink. . . . . . 15.00

Purple Crown, Dark Scarlet with Yellow Border . 6.00

Rosamundi, Pink and White, fine bedder..... 5.25

Rose Gris de Lin. The great demand for this beautiful tulip, the finest pink for all purposes, is well known, per $10,000 \$ 50.00 \ldots \ldots \ldots \ldots$. . . . . . .

Rose Luisante, Deep Satiny Pink. . . . . . . . . . . . . .

Standard Royal Silver White, feathered with Crimson, very fine bedder . . . . . . . . . 10.00

Jacoba van Beieren, Pure White.............. 4.00

Primrose Queen, a fine sulphur Yellow forcer. . 12.00

Prince de Ligny, Deep Yellow, long-stemmed. . . 5.00

Ophir d'Or, Golden Yellow, fine bedder . . . . .... 7.50

Thomas Moore, the finest Early Orange for forcing $\quad 4.00$

New Pink, an excellent Bright. Pink and White for bedding......................

Vermilion Brilliant. Of this we have the true variety. It is the finest of all Scarlets for forcing

White Hawk, or Albion Pure White.... . . . . . . .

Yellow Prince. No doubt the most used of all Yellows for forcing. For outdoor work we would rather recommend Chrysolora or Gold Finch, per $10,000 \$ 48.00 \ldots \ldots \ldots \ldots \ldots \ldots$

24.00

12.50

10.00

\section{DOUBLE EARLY TULIPS.}

Per 1000

$\$ 4.50$

Fine Mixed Double Early.

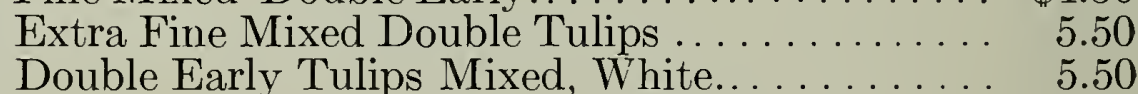

214 Double Early Tulips Mixed, White........... . 5.50

216

217

218

DOUBLE EARLY TULIPS NAMED.

Couronne d'Or. The best Double Yellow forcer, extra heavy bulbs. . . . . . . . . . . . . . . . . . \$ \$10.50

220 Couronne de Roses, Deep Pink.............. 20.00

221 Imperator Rubrorum, Fine Bright Scarlet....... . 12.00

222 La Candeur, Pure White, good bedder.......... 7.75

223 Le Blazon, Pink and White .

224 Le Matador, Bright Scarlet, for all purposes . . . . 13.00 
226 Lucretia, one of the best Pink forcers. . . . . . . . 22.00

227 Murillo, Extra Fine Light Pink, the best trade varietr in its color, fancr, $\$ 9.00$; first grade. . $\quad 7.00$

Purple Crown, Purplish Red............. 7.00

Rex Rubrorum, Scarlet, bedder. . . . . . . . . . 9.00

Rose a Merreilie, Rosr Red............. 6.00

232 Rose Blanche, Pure IThite . . . . . . . . . . .
233 Rosina, one of the best early deep Pink, semidouble...................... 13.00

234 Rubra Maxima, Deep Red, good for all purposes.

Ma Cousine, Rosy Pink

Salvator Rose, Deep Pink ....................... 5.00

Titian, Brown and Yellow.............. 9.50

237 Titian, Brown and Yellow ...................... early.

239 Tournesol Yellow. One of the finest early Yellows

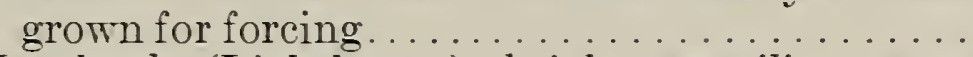

240 Tuurbaak (Lighthouse) bright vermilion, very strong, and one of the best double scarlets for forcing.

Gloria Solis, Red and Yellow.

Duc ran Thol, Red and Yellow.

Yellow Rose, Sweet Scented Dark Yellow........ 6.00

\section{SINGLE LATE TULIPS.}
Extra fine Mixed Late Tulips

\section{PARROT TULIPS.}

Constantinople, Red.

Lutea, Large Yellow. . . . . . . . . . . . . . . . . . 6.00

Perfecta Yellow, Scarlet feathered............ 6.00

Couleur Café, Orange, feathered yellow....... 6.00

Cramoisi Brilliant, Carmine Red ........... 6.00

Parrot Tulips, Finest Mixed .............. 3.50

\section{DARWIN TULIPS.}

Darwin Tulips, Superfine Mixed ........... 6.00

\section{SINGLE MAY FLOWERING TULIPS.}

261 Bouton d'Or, Golden Yellow, fine for outdoor cutting ........................... $\$ 5.50$

262 Bizares, Very Fine Mixed.............. 6.00

263 Bybloems, Very Fine Mixed. . . . . . . . . . . . 5.50

264 Gesneriana Spathulata, Dazzling Scarlet ....... 6.50

265 Isabella, Cream turning to Carmine Red ....... 6.00

266 White Swan, Pure White egg-shaped flower..... 6.00

267 Golden Eagle, Yellow and Red............ 5.50

268 Macrophyla, Carmine Red, with black center marked Yellow....................... 4.50

269 Sweet Nancy, White and Pink............ 4.50

270 Maiden's Blush, or Picotee, White, margined pink 6.75

271 Golden Crown, Yellow, margined red........ 4.25 


\section{NARCISSUS.}

Our stock of Narcissus is ever rogued out; hence we offer only bulbs of superior quality and at very reasonable prices.

\section{SINGLE DAFFODILS.}

272 Bicolor Horsefieldii, Pure White Perianth, with vellow trumpet ..................... \$6.00

273 Bjcolor Emperor, Deep Yellow Trumpet, with Primrose Perianth, a very large flower of great substance, first size, $\$ 8.00$; mother bulbs.....

274 Bicolor Empress, Pure White, with yellow trumpet, first size, $\$ 8.00$; mother bulbs. . . . . . . . .

275 Bicolor Golden Spur, the best of the Yellow Daffs, first size, \$8.50; mother bulbs . . . . . . . . . . 14.00

276 Bicolor Princeps, fine for forcing and very reasonable.

277 Bicolor Victoria, Sweet Scented White Perianth, large yellow trumpet, a very large flower and the best of the Bicolors.................

Single Van Sion, Yellow, forces very early and easy Incomparabilis, Simplex, fine for cutting. . . . . . . $"$ Stella, White and Yellow ....... " Sir Watkins, Sulphur Yellow Perianth, cup orange yellow. . Cynosure, Sulphur White Petals, Yellow Cup.............

Mrs. Langtry, Pure White................

Poeticus, Pure White, sweet scented...........

sweet for forcing, first size. .

Jonquils Campanulata Regulosus, Large Golden Yellow.

\section{DOUBLE NARCISSUS.}

Alba Plena Odorata, sweet like Gardenia Flowers,

fine outdoors, not for forcing . . . . . . . . . . $\$ 3.00$

289 Incomparabilis, fl. pl. Yellow ................ $\quad 5.00$

290 Orange Phoenix, White and Orange ........... 5.75

291 Silver Phoenix, White and Sulphur, very fragrant 8.50

292 Double Van Sion, second size, very fine bulbs, 7.00 First size, extra selected strong bulbs................ 9.00

Double nosed . . . . . . . 13.00

Mother bulbs, very heavy .... 16.00

Van Sion with us is a specialty, and we are growing immense quantities of them, enabling us to furnish extra fine stock.

For very large quantities let us quote you special prices.

\section{NARCISSUS POLYANTHUS.}

Grand Monarque, White Yellow Cup . . . . . . . . \$13.50

294 Staten General, White................... 12.00

295 Grand Soleil d'Or, Yellow with Orange Cup . . . . . 13.00

296 Gloriosus, White with Orange Cup . . . . . . . . 13.50

297 Grand Primo, White...................... 13.00

298 Jaune Suprème, Yellow with Orange Cup . . . . . 15.00

299 Newton, Yellow with Orange Cup . . . . . . . . . 22.00

300 The Pearl. Pure White, extra large.......... 16.00 


\section{SPECIAL NEW.}

\section{NARCISSUS-Top Size Bulbs Only.}

304 New Foundling. A norelty pure white, with dark yellow cup, bearing twenty or more flowers, forces very easy. This new grand variety you should get acquainted with, one of the best acquisitions to the bulb family in years, per 10 $\$ 1.50$

Poeticus Admiration. Another grand novelty well worth its name. Unlike the other poeticus varieties which generally bear single flowers, this new poet bears grand, large, bright orange flowers in clusters. The stock is very limited yet. Forces well. 25 cents each; per $10, \$ 2.00 \ldots$.

Narcissus per 100 , add 10 per cent. to 1000 rate.

\section{CROCUS.}

306

Fine Purple, Mixed

Fine General Mixed

Crocus, Mont Blanc

" King of the White

" Sir Walter Scott, White Striped Purple

\section{IRIS HISPANICA.}

Belle Chinoise, Yellow

Louise, Blue, light.................. 2.50

Alex Von Humboldt, D. Blue . . . . . . . . . . . . 2.50

Cajanus, Golden Yellow, late............ 2.75

La Reconnaissance, D. Bronze............. 2.75

Iris Hispanica, Mixed, all colors, per 10,000, \$\$.50; per $100,000, \$ 65.00$

\section{IRIS ANGLICA.}

Iris anglica in 20 named varieties

\section{GLADIOLUS}




\section{MISCELLANEOUS BULBS.}

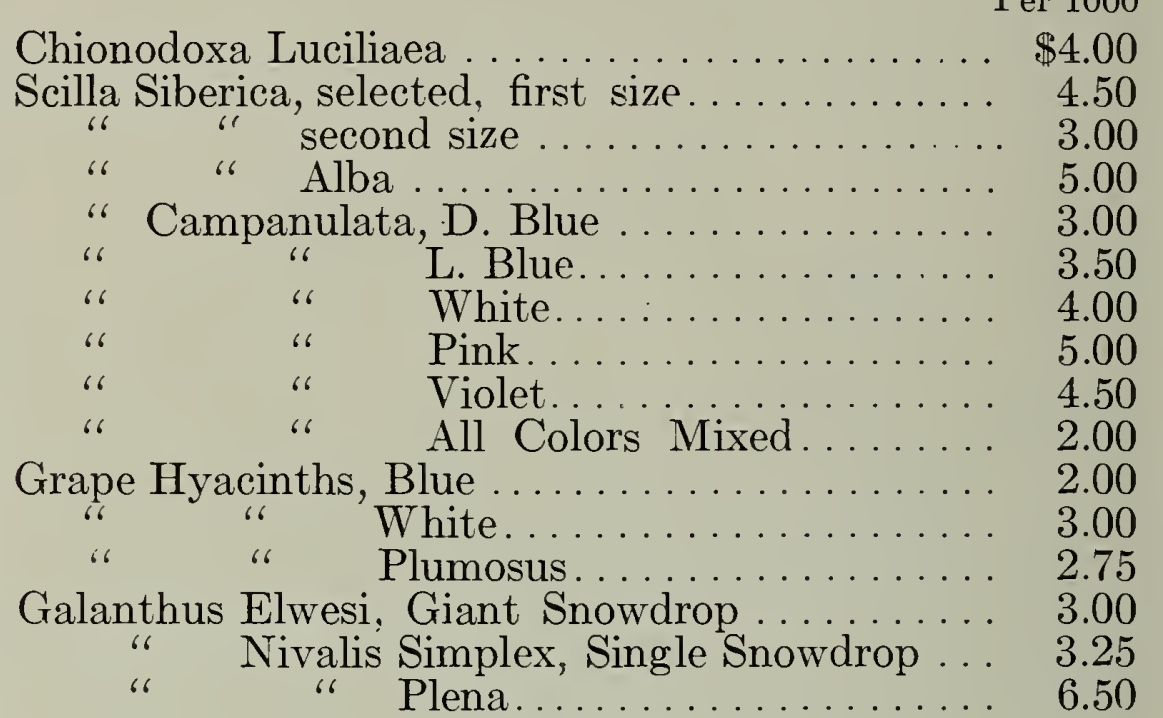

The OLD WAY - Wait for weeks for any quotations or information.

The NEW WAY - Telephone-telegraph-write to the HORTICULTURAL COMPANY-ANY TIMEand get your quotations AT ONCE.

Send us your want lists for quotations. IT PAYS. 


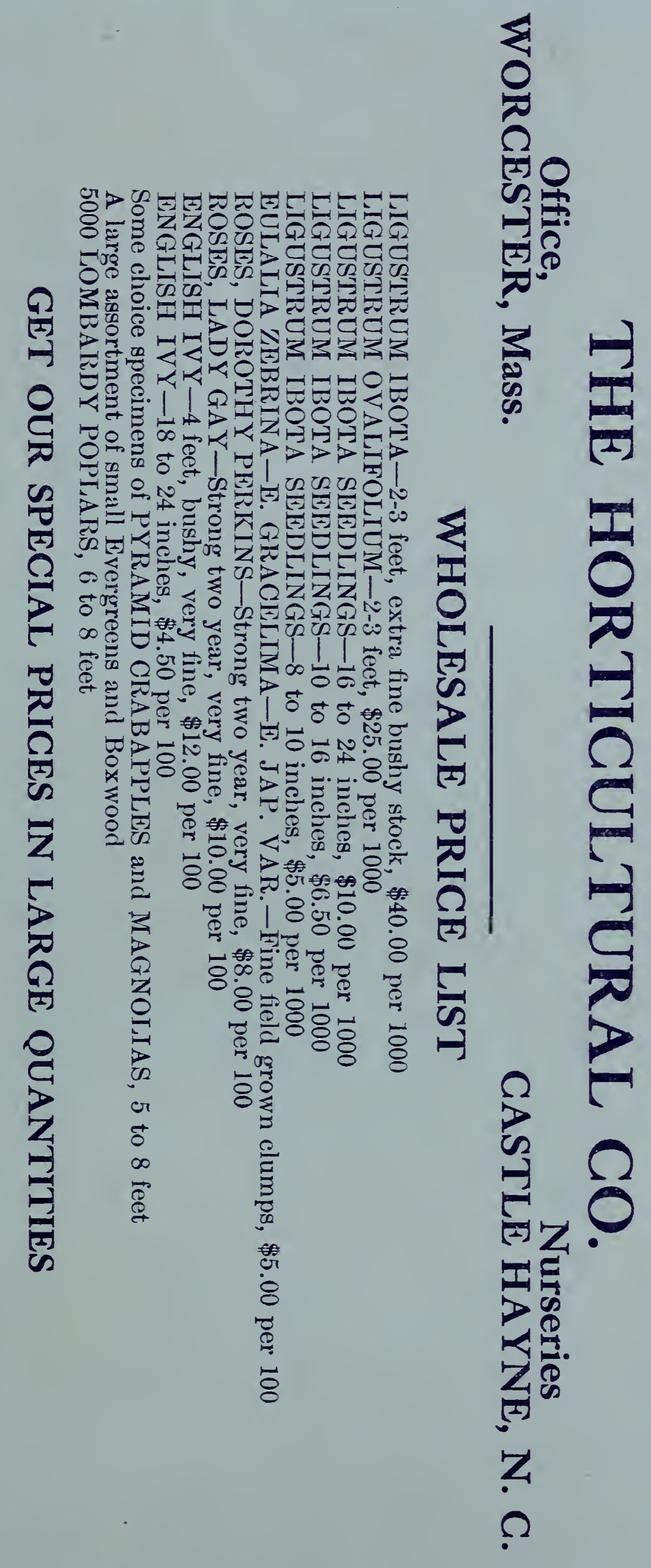





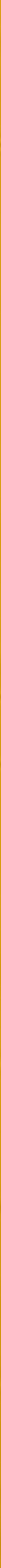




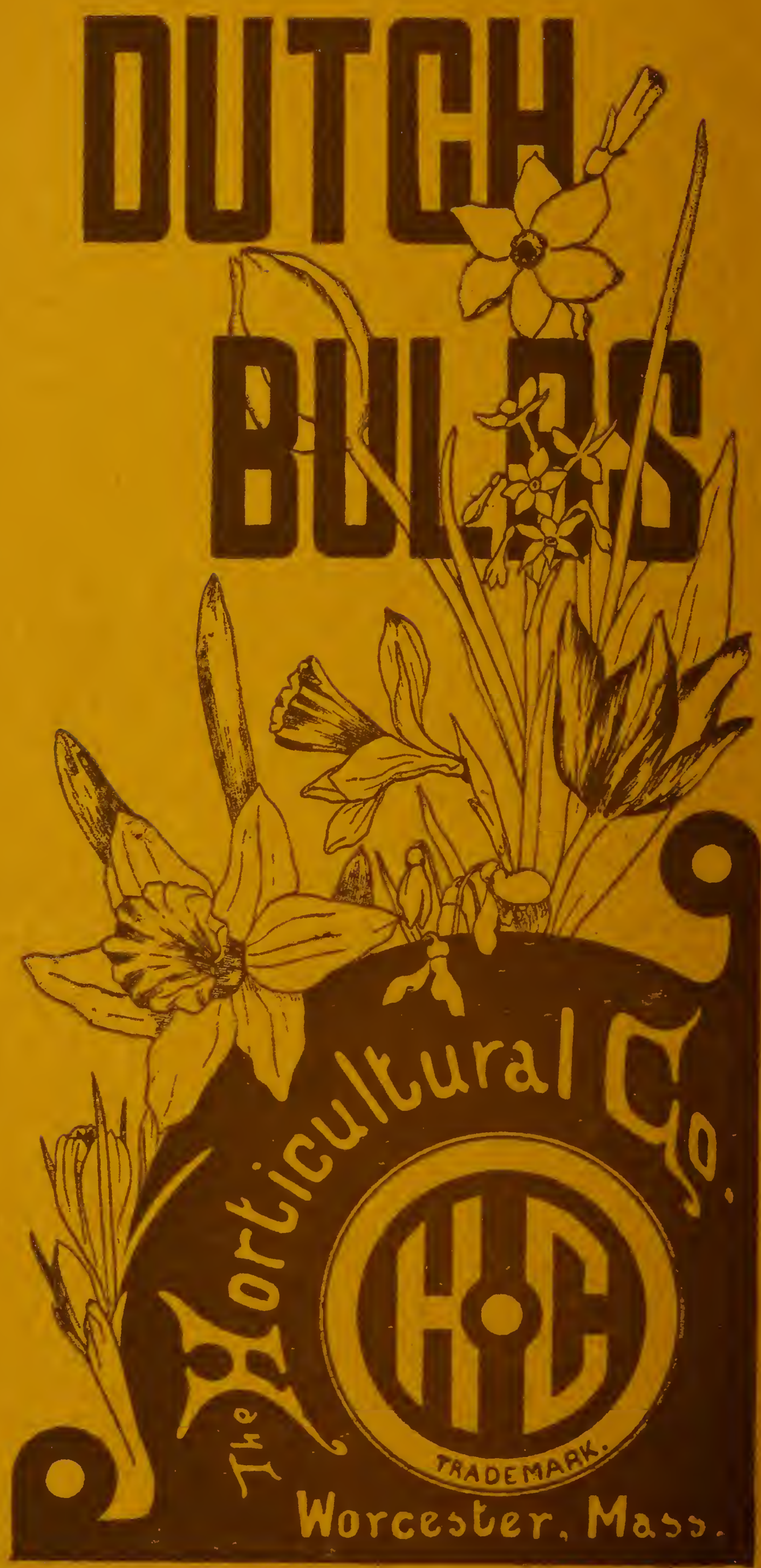

